\title{
Duhom ispunjeni evangelizatori
}

\author{
RICHARD PAVLIĆ* \\ • https://doi.org/10.31823/d.27.4.7 • \\ UDK: 27-766-732.2 • Pregledni članak \\ Primljeno: 10. srpnja 2019. • Prihvaćeno: 2. prosinca 2019.
}

Sažetak: Duhom ispunjeni evangelizatori naslov je petoga poglavlja apostolske pobudnice pape Franje Evangelii gaudium. Članak se bavi promišljanjem tzv. duhovnih pretpostavki evangelizacije koje otkrivamo u tom dijelu Papine pobudnice. Tekst članka podijeljen je u tri dijela. U prvom dijelu na sažet način promatramo pojmove evangelizacije i misijske djelatnosti Crkve kroz povijesni razvoj papinske misli od pape Pavla VI., preko Ivana Pavla II. i Benedikta XVI., do pape Franje. Tim slijedom u drugom dijelu clanka promatramo temu evangelizacije u misli pape Franje kroz prizmu kontinuiteta i novosti u odnosu na njegove prethodnike. Treći dio članka dovodi nas do ciljne teme, a to je govor o Duhom ispunjenim evangelizatorima, gdje posebno izdvajamo tri duhovne pretpostav-

* doc. dr. sc. Richard Pavlić, Katolički bogoslovni fakultet Sveučilišta u Zagrebu, Teologija u Rijeci, Područni studij, Omladinska 1, 51000 Rijeka, Hrvatska, ripavlic@gmail.com ke evangelizacije koje nam sugerira papa Franjo: otvorenost Duhu Svetomu, zajedništvo s Marijom te uvjetno-posljedična tema radosti plodnoga naviještanja evandelja.

Ključne riječi: evangelizacija, nova evangelizacija, misije, $\mathrm{Pa}$ vao VI., Ivan Pavao II., Benedikt XVI., Franjo, Evangelii gaudium.

\section{Uvod}

U kontekstu šire teme o evangelizaciji ovdje govorimo o Duhom ispunjenim evangelizatorima prema apostolskoj pobudnici pape Franje Evangelii gaudium. ${ }^{1}$ Kontekst teme određuje tzv. postkršćanska era te novi izazovi evangeliza-

${ }^{1}$ FRANJO, Evangelii gaudium - Radost evandelja. Apostolska pobudnica biskupima, prezbiterima i đakonima, posvećenim osobama i svim vjernicima laicima o naviještanju evanđelja u današnjem svijetu, Zagreb, 2013. (=EG). 
cije koji su bili predmet međunarodnoga znanstvenoga simpozija Radost naviještanja Krista. Evangelizacija u postkršćanskoj eri, održanoga na Teološko-katehetskom odjelu Sveučilišta u Zadru od 19. do 20. travnja 2018. godine.

Pontifikat pape Franje smješta se u kontekst suvremenih izazova sekulariziranoga svijeta u kojem se gube jasne razlike između kršćanskih i nekršćanskih zemalja. To $\mathrm{mu}, \mathrm{u}$ odnosu na njegove prethodnike, otvara novu perspektivu poimanja evangelizacije i njezinih čimbenika, naroda i kulture te samih evangelizatora, službenika evanđelja. Iako donosi nove naglaske i vlastite uvide, papa Franjo ne zanemaruje već stečeno učiteljsko nasljeđe u vlastitom poimanju evangelizacije, redovitoga pastorala i misijskoga djelovanja Crkve. Sve to jasno dolazi do izražaja u posljednjem poglavlju njegove pobudnice Evangelii gaudium, naslovljenom Duhom ispunjeni evangelizatori, koje je predmet našega promišljanja.

\section{Evangelizacija i misijsko djelovanje Crkve}

Pojam evangelizacije u povijesti Crkve postupno je postao sinonim za redoviti pastoral i katehezu. To se posebno odnosi na razdoblje nakon Tridentskoga koncila i to na europsko društvo s većinskim kršćanskim stanovništvom, gdje se vjera prenosila u obiteljima, s koljena na koljeno. No već u 19. st., s pojavom napuštanja vjere pojedinaca ili obitelji, društvo se više nije moglo smatrati u cijelosti kršćanskim te se počinje govoriti o potrebi evangelizacije osoba, pojedinaca koji su napustili vjeru. $^{2}$

Unatoč tomu papa Pavao VI. u svojoj pobudnici Evangelii nuntiandi ${ }^{3}$ govori o evangelizaciji u globalnom smislu, s posebnim naglaskom na tada aktualnu dijalektiku između evangelizacije i ljudskoga napretka. Ivan Pavao II. uvodi pojam nove evangelizacije i to u kontekstu masovne pojave sekularizacije europskoga društva. No i ovdje je pojam evangelizacije kao nove evangelizacije shvaćen u prilično globalnom smislu, usmjeren ponajprije prema javnim sferama pojedine države, naroda ili društva općenito, kulturi i politici, a manje pojedincu. I papa Benedikt XVI. nastavlja na toj liniji, štoviše, ne dajući prednost pojedinim državama ili narodima, on ide na izvore kršćanske kulture, na spoj grčkoga lógosa i biblijske objave. On apelira na razum kao zajedničku baštinu kršćanstva i čovječanstva općenito, ali upozorava i na slabosti ljudskoga razuma i posljedičnu pojavu relativizma u društvu. ${ }^{4}$

\footnotetext{
${ }^{2}$ Usp. S. DIANICH, Učiteljstvo pape Franje - nove perspektive, u: Riječki teološki časopis 24(2016.)2, 329-350., ovdje 333.

${ }^{3}$ PAVAO VI., Evangelii nuntiandi. Apostolski nagovor o evangelizaciji u suvremenom svijetu, Zagreb, 1976. (= EN).

${ }^{4}$ Usp. S. DIANICH, Učiteljstvo pape Franje - nove perspektive, 333-336.
} 
Paralelno $s$ tako nijansiranim poimanjem evangelizacije koja se odnosi prije svega na kršćanske zemlje postoji misijsko djelovanje Crkve koje je usmjereno na širenje evanđelja u nekršćanskim zemljama. Možemo reći da je to razlikovanje evangelizacije i misija još uvijek prisutno u Crkvi. Ivan Pavao II. u enciklici Redemptoris missio poima misijsko djelovanje Crkve ad gentes, kao različito od redovite pastoralne skrbi vjernika ili nove evangelizacije onih koji ne prakticiraju vjeru. Misijski se djeluje $\gg$ na posve drugačijim i odijeljenim područjima i zajednicama ljudi «..$^{5}$ kod pape Benedikta XVI. govor o novoj evangelizaciji odnosi se ponajviše na narode koji ba-

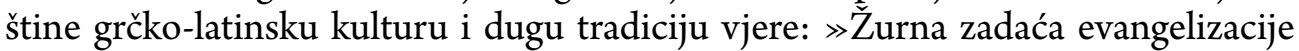
ostvaruje se na razne načine ovisno o specifičnoj situaciji pojedinih naroda. Postoji poslanje ad gentes u pravom smislu riječi prema onima koji Krista ne poznaju. U širem smislu riječi, govorimo o evangelizaciji u redovitom pastoralu, a o novoj evangelizaciji u odnosu na one koji više ne prakticiraju svoje kršćanstvo. ${ }^{6}$

Ako u ovom kontekstu pokušamo sagledati pojam evangelizacije u učiteljstvu pape Franje, nailazimo na jednu novu perspektivu uvjetovanu brzim promjenama $u$ društvu u nekoliko posljednjih desetljeća: migracijske promjene u Europi, sekularizacijske silnice u suvremenom društvu, pojava multikulturalnosti i multireligioznosti, ponovno jačanje antiklerikalizma i ostali suvremeni izazovi za kršćansku vjeru i kulturu. Zahvaljujući tim promjenama, s pravom se možemo pitati: Može li se suvremeni svijet još uvijek dijeliti na kršćanske i nekršćanske zemlje? Naime kod pape Franje, u odnosu na njegove prethodnike, nalazimo jedno drukčije poimanje naroda i kulture. On narod ne poima u nacionalnom smislu, nego više u teološkom smislu naroda Božjega. Zato nije toliko zaokupljen pozivanjem pojedinih naroda na tradicionalne korijene kršćanske kulture. Iako ne umanjuje vrijednost evangelizirane kulture, on upozorava na opasnu $\gg$ sakralizaciju « vlastite kulture: $\gg$ Poruka koju naviještamo uvijek je zaodjenuta u neko kulturno ruho, no katkad u Crkvi upadamo u taštu i nepotrebnu sakralizaciju vlastite kulture, čime možemo više pokazati fanatizam nego autentičan evangelizacijski žar. $\ll^{7}$

\section{Misijska preobrazba Crkve: Novost u kontinuitetu}

Unatoč toj novoj perspektivi, uvjetovanoj novim izazovima evangelizacije, uspoređujući i ovdje papu Franju s njegovim prethodnicima, možemo primijetiti sna-

\footnotetext{
${ }^{5}$ Usp. IVAN PAVAO II., Redemptoris missio. Enciklika o trajnoj vrijednosti misijske naredbe, Zagreb, 1991. (= RM), br. 37.

${ }^{6}$ BENEDIKT XVI., Africae munus. Esortazione apostolica postsinodale all'episcopato, al clero, alle persone consacrate e ai fedeli laici sulla Chiesa in Africa al servizio della riconciliazione, della giustizia e della pace, Oudiah, Benin, br. 60. Usp. S. DIANICH, Učiteljstvo pape Franje - nove perspektive, 336.

${ }^{7}$ EG, br. 117; usp. S. DIANICH, Učiteljstvo pape Franje - nove perspektive, 339.
} 
žan kontinuitet. Naime brojne teme koje papa Franjo preferira često se prikazuju kao nove, iako nisu toliko nove, na primjer govor o Crkvi koja izlazi, govor o evanđeoskoj radosti te u ovom slučaju, govor o misijskoj obnovi Crkve. U tom smislu Evangelii gaudium zapravo je logičan nastavak niza magisterijalnih dokumenata koji svoj impuls nalaze u koncilskom dekretu Ad gentes o misijskoj djelatnosti Crkve. ${ }^{8}$ Mislimo prije svega na već spomenutu apostolsku pobudnicu Pavla VI. Evangelii nuntiandi te encikliku Redemptoris missio pape Ivana Pavla II. Osim toga Evangelii gaudium predstavlja odgovor na zahtjeve XIII. redovite biskupske sinode na temu Nove evangelizacije za prenošenje vjere (2012. - 2013.).

Uzimajući dakle u obzir već stečeno učiteljsko nasljeđe, kod govora o evangelizaciji u suvremenom društvu papa Franjo daje nove naglaske i vlastite uvide. Iako se koristi izrazom nova evangelizacija, on tom pojmu ne daje prednost jer za njega je svaka autentična evangelizacija uvijek nova: $\gg$ Svaki put kada se trudimo vratiti izvoru i ponovno otkriti izvornu svježinu evanđelja, javljaju se novi putovi, kreativne metode $s$ različitim oblicima izraza, rječitiji znakovi, riječi bremenite novim značenjem za današnji svijet. Zapravo svako evangelizacijsko djelovanje uvijek je 'novo' «" Osim toga papa Franjo evangelizaciju stavlja u kontekst redovitoga pastorala, koji ne isključuje ni nevjernike ni vjernike koji su se udaljili od vjere: »Svi imaju pravo primiti evanđelje. Kršćani imaju zadaću naviještati ga ne isključujući nikoga. ${ }^{10}$

Kako dakle papa Franjo poima evangelizaciju? Prije svega u kontekstu misijske preobrazbe Crkve, i to cijele Crkve, bez podjele na kršćanske i nekršćanske narode. Riječ je o pastoralu misijskoga stila, misijskoga ključa koji obuhvaća cijelu Crkvu. Takva vrsta pastorala zahtijeva odricanje od neplodne sigurnosti: »Pastoral u misijskom ključu traži da se napusti lagodni pastoralni kriterij koji se vodi onim 'uvijek se radilo tako'. $\ll{ }^{11}$ To je pastoral u preobrazbi, koji zahtijeva da Crkva samu sebe shvati kao zajednicu u trajnom stanju evangelizacije. To zahtijeva pomak od logike »pastorala očuvanja « prema evangelizacijskomu pastoralu. ${ }^{12}$

Drugi naglasak u suvremenom poimanju evangelizacije u naučiteljstvu pape Franje otkrivamo u tipu tzv. poosobljenoga pastorala, u jednom obliku personalnoga misijskoga djelovanja: »od osobe do osobe «. Upravo tako je naslovljeno nekoliko

\footnotetext{
${ }^{8}$ DRUGI VATIKANSKI KONCIL, Dekret o misijskoj djelatnosti Crkve »Ad gentes «, u: ISTI, Dokumenti, Zagreb, ${ }^{72008 . ~(=A G) . ~}$

${ }^{9} \mathrm{EG}$, br. 11.

${ }^{10}$ EG, br. 14; usp. S. DIANICH, Učiteljstvo pape Franje - nove perspektive, 338-339.

${ }^{11}$ EG, br. 33.

${ }^{12}$ N. VRANJEŠ, Aktualnost apostolske pobudnice Evangelii gaudium pape Franje, u: Diacovensia 22(2014.) 4, 447-468., ovdje 449-450.
} 
brojeva Papine pobudnice. ${ }^{13}$ Interpersonalne odnose papa Franjo smatra glavnim nositeljima evangelizacije te u tom kontekstu osuđuje »depersonalizaciju « pastorala. ${ }^{14}$

Metoda koju Papa smatra prikladnom za takvu vrstu pastorala i evangelizacije jest evanđeosko razlučivanje. Spominje ga na više mjesta u svojoj pobudnici. ${ }^{15} \gg$ Ono što želim ponuditi $\ll$ - kaže Papa - »više je povezano s evanđeoskim razlučivanjem. To je pristup učenika misionara koji se hrani svjetlom i snagom Duha Svetoga. $\ll{ }^{16}$ Pozivajući se i ovdje na svoje prethodnike, Pavla VI. i Ivana Pavla II., papa Franjo to evanđeosko razlučivanje vidi kao metodu otkrivanja poticaja Duha Svetoga za djelovanje Crkve danas: »pozivam sve zajednice da imaju 'uvijek budnu sposobnost proučavanja znakova vremena. $\ll{ }^{17}$

\section{Evangelizatori u Duhu}

Ovdje se približavamo Franjinom poimanju $\gg$ evangelizatora $\mathrm{u}$ Duhu $\ll$. To ne će biti prije svega $\gg$ stručnjaci «, nego $\gg$ svaki krštenik «: $\gg$ Svaki krštenik, neovisno o položaju u Crkvi i stupnju vjerske izobrazbe, aktivni je nositelj evangelizacije. $\ll^{18}$ Takav tip pastoralno-misijskoga djelovanja zahtijeva odgovarajući tip duhovnosti. Upravo toj temi posvećeno je cijelo peto poglavlje Franjine pobudnice, naslovljeno Duhom ispunjeni evangelizatori, iako se pitanje duhovnosti provlači cijelim dokumentom, osobito u završetku drugoga poglavlja pobudnice. Riječ je o svojevrsnim duhovnim pretpostavkama evangelizacije koje papa Franjo sažima u petom poglavlju svoje pobudnice.

Dvije su riječi ovdje u igri: duhovnost (lat. spiritualitas) i poslanje (lat. missio). Općenito poimanje duhovnosti (spiritualitas) odnosi se na određeni način života koji pretpostavlja postojanje duhovnoga svijeta s kojim čovjek nastoji biti u relaciji, dijalogu i zajedništvu. Specifično kršćansko poimanje duhovnosti nalazimo sažeto u novozavjetnoj antropologiji sv. Pavla prema kojoj je cijeli čovjek unatoč napetosti između duhovnoga, duševnoga i tjelesnog aspekta vlastitoga bića nanovo rođen obnovljen po Duhu Isusa Krista: »Svi koje vodi Duh Božji sinovi su Božji (Rim 8, 14; usp. Rim 5, 5; 8, 9.16). Kršćanska je dakle duhovnost »život u Duhu Isusa

\footnotetext{
${ }^{13}$ Vidi EG, br. 127-129.

${ }^{14}$ Usp. EG, br. 82.

${ }^{15}$ Usp. EG, br. 43, 45, 46 i dr.

${ }^{16} \mathrm{EG}$, br. 50.

${ }^{17}$ EG, br. 51; usp. N. VRANJEŠ, Crkva koja izlazi, 452.

${ }^{18}$ EG, br. 120.
} 
Krista «, odnosno praktičan život u duhu evanđelja Isusa Krista, u skladu sa zakonom evanđelja. ${ }^{19}$

Druga riječ jest poslanje, od latinskoga glagola mittere - 'poslati, biti dakle poslan, imati poslanje'. U kršćanskoj perspektivi odnosi se izravno na Isusovu zapovijed, poslanje svojim učenicima: »Pođite dakle i učinite mojim učenicima sve narode krsteći ih u ime Oca i Sina i Duha Svetoga i učeći ih čuvati sve što sam vam zapovjedio! $($ Mt 28, 19-20). Teološki korijen toga poslanja jest u samome trojstvenome Bogu, iz kojega se rađa poslanje Crkve, kako nam to doziva u svijest spomenuti koncilski dekret o misijskoj djelatnosti Crkve: »Crkva u hodu jest 'misionarska' po svojoj naravi, jer potječe iz slanja Sina i slanja Duha Svetoga po odluci Boga Oca. $\ll^{20}$ Svaki je dakle kršćanin ucijepljen u Krista, a time i u njegovo spasenjsko poslanje, odnosno misijsko djelovanje. ${ }^{21}$

Drugi vatikanski koncil jasno razvija trinitarnu ekleziologiju te podsjeća na misionarsku narav Crkve. Slijedeći taj koncilski impuls, papa Pavao VI. u Evangelii nuntiandi govori o $\gg n u t a r n j e m ~ s t a v u$ koji mora pokretati onoga koji radi na evangelizaci$\mathrm{ji} \ll \mathrm{i}$ tu, među ostalim, naglašava vjernost Duhu Svetomu i Marijinu prisutnost kao »uvjete koji će evangelizaciju učinit ne samo mogućom, nego također djelotvornom i plodonosnom $\ll^{22}$. Ivan Pavao II. u Redemptoris missio govori eksplicitno o $\gg$ misijskoj duhovnosti < koja, među ostalim, podrazumijeva sljedeće: podložnost Duhu Svetomu; intimno jedinstvo s Kristom iz kojega proizlazi ljubav prema Crkvi i ljudima te osobna svetost misionara. ${ }^{23}$

Ne čudi nas da sve te spomenute naglaske nalazimo kod pape Franje u posljednjem, petom poglavlju njegove pobudnice Evangelii gaudium. Dovoljno je u tom smislu baciti pogled na sadržaj petoga poglavlja pobudnice, u kojem s lakoćom uviđamo spomenute naglaske. Možemo dakle zaključiti da papa Franjo i ovdje ostaje vjeran učiteljskom nasljeđu svojih prethodnika, iako ne na tako sustavan način. Tako $\mathrm{u}$ drugom poglavlju njegove pobudnice nalazimo njegovo veliko $\gg$ da $\ll$ izazovima misijske duhovnosti, ${ }^{24}$ ali nakon toga ne ide odmah na bit te duhovnosti, nego nastavlja u stilu »via negationis« nabrajajući »demone« protivne istinskoj misijskoj

\footnotetext{
${ }^{19}$ Usp. J. U. OZIOKO, Evangelii Gaudium: A Precious Treasure for Cultivating the Missionary Spirituality, u: Alpha Omega 19(2016.)2, 223-252., ovdje 226-228.

${ }^{20}$ AG, br. 2.

${ }^{21}$ Usp. J. U. OZIOKO, Evangelii Gaudium, 228-230.

${ }^{22} \mathrm{EN}$, br. 74.

${ }^{23}$ Usp. EN, br. 87-88, 90-91; J. U. OZIOKO, Evangelii Gaudium, 230-231.

${ }^{24}$ EG, br. 76-80.
} 
duhovnosti: egoizam, sterilni pesimizam, svjetovna duhovnost, zavist i $\mathrm{dr}^{25} \mathrm{Od}$ pozitivnih naglasaka u cijeloj Papinoj pobudnici otkrivamo teme radosti, susreta, svijesti o božanskom primatu, zatim kristocentričnost, upornost, bratsku ljubav, vodstvo Duha Svetoga te zajedništvo s Marijom. Od nabrojenih tema ovdje bismo posebno izdvojili tri: govor o Duhu Svetome, Marijina prisutnost i zagovor te tema evanđeoske radosti. Riječ je o trima međusobno povezanim naglascima koje susrećemo u Franjinoj pobudnici. Prva dva osobito su zastupljena u završnom dijelu pobudnice, dok tema radosti prožima cijeli tekst pobudnice. Sve tri teme povezane su ekleziokristocentričnom perspektivom i naučiteljskim kontinuitetom.

\subsection{Duh Sveti}

Kod govora o Duhu Svetome naučiteljski kontinuitet otkrivamo najprije u koncilskome dekretu Ad gentes, gdje se spominje otajstveno djelovanje Duha Svetoga kod Krista, Marije i apostola: »Od Duhova naime otpočeše 'djela apostolska', kao što je Krist začet silaskom Duha Svetoga nad Djevicu Mariju i kao što je Krist uveden u djelo svoje službe silaskom istoga Duha Svetoga na njega dok se molio. ${ }^{26}$ Zatim u Evangelii nuntiandi pape Pavla VI., gdje izdvajamo sljedeće: »Bez djelovanja Duha Svetoga evangelizacija uopće nije moguća. (...) Ima u evangelizaciji niz metoda koje su dobre, ali ni najsavršenije od njih ne bi mogle nadomjestiti tiho djelovanje Duha. Bez njega ništa ne vrijedi ni najvještija priprava navjestitelja. I najuvjerljivija oštroumnost bez njega je pred ljudskim duhom bespomoćna. Sve psihološke i sociološke, do u tančine razrađene sheme, bez njega se ubrzo pokazuju bezvrijednima. $\ll{ }^{27} \mathrm{Te}$, konačno, u Redemptoris missio pape Ivana Pavla II. koji ističe da se misijska duhovnost izražava prije svega kao »život u potpunoj podložnosti Duhu Svetome $\ll^{28}$

Sjetimo se također da je tema nazočnosti Duha Svetoga, odnosno svijest o nazočnosti i djelovanju Duha Božjega, bila aktualna u pripremi za slavlje ulaska u treće tisućljeće kršćanstva. Papa Ivan Pavao II. odredio je da se 1998. godina $\gg$ na poseban način posveti Duhu Svetome i njegovoj posvećujućoj prisutnosti unutar Zajednice Kristovih učenika $\ll{ }^{29}$ Brojna teološko-pastoralna promišljanja u toj godini imala su za temu svojevrsnu $\gg$ krizu duha $\ll$, odnosno $\gg$ odsutnost duha $\ll u$ suvremenome društvu. Uzroci te krize mogu se sagledati u filozofsko-teološkim korijenima

\footnotetext{
${ }^{25}$ Usp. EG, br. 81-101.

${ }^{26} \mathrm{AG}, \mathrm{br} .4$.

${ }^{27} \mathrm{EN}$, br. 75 .

${ }^{28}$ RM, br. 87.

${ }^{29}$ IVAN PAVAO II., Tertio millenio adveniente - Nadolaskom trećeg tisućljeća, Zagreb, 1996. (= TMA), br. 44.
} 
europskoga društva, odnosno u povratku antičkom poimanju duha koje se bitno razlikuje od biblijsko-teološkoga poimanja duha. ${ }^{30}$ Biblija nudi personalno shvaćanje duha koje se postupno razvija u govor o Duhu Svetome kao jednoj od triju božanskih osoba. Takvo trojstveno personalno poimanje Duha podrazumijeva kvalitete zajedništva, dijaloga, komunikacije i otvorenosti. Upravo su ti naglasci imali odjeka $\mathrm{u}$ antropološko-ekleziološkim postavkama Drugoga vatikanskoga koncila. ${ }^{31} \mathrm{Na}$ liniji koncilskoga optimizma ta »kriza duha « suvremenoga čovjeka može se pozitivno vrjednovati jer ona ne mora označavati posvemašnju odsutnost duha, nego samo njegovu »drukčiju prisutnost, tj. prisutnost u modusu odsutnosti $\ll^{32}$

Koncilski antropološko-ekleziološki optimizam te biblijsko, trojstveno-personalno poimanje Duha Svetoga otkrivamo i kod pape Franje. On razlikuje opće, antropološko poimanje duha od trojstveno-personalnoga govora o Duhu Svetome. Prvo se odnosi na $\gg$ neki nutarnji poticaj koji ohrabruje, motivira, jača i daje smisao osobnom i zajedničkom djelovanju $\ll^{33}$, dok se govor o Duhu Svetome spominje u kontekstu evangelizacije koja bi bez toga istoga Duha, unatoč svim nutarnjim poticajima i motivacijama, bila besplodna. ${ }^{34}$

Sama riječ $d u h$ u odnosu na Duha Svetoga spominje se u Evangelii gaudium više od 85 puta i to redovito u spomenutom evangelizacijsko-misionarskom djelovanju Crkve. U tom smislu papa Franjo govori o današnjim evangelizatorima $\gg$ koji se bez straha otvaraju djelovanju Duha Svetoga $\ll^{35}$ i koji imaju odlučno povjerenje u Duha Svetoga koji »potpomaže našu nemoć« $(\operatorname{Rim} 8,26) .{ }^{36} \mathrm{Ta}-$ kve evangelizatore karakterizira specifična duhovnost koja predstavlja spoj akcije i kontemplacije, ${ }^{37}$ a svoj najjači izraz postiže u obliku zagovorne molitve koja $\gg$ ne odvaja od prave kontemplacije, jer u istinskoj kontemplaciji uvijek ima mjesta za

\footnotetext{
${ }^{30}$ Povrat antičkomu poimanju duha od početnoga Descartesova dualizma, preko Spinoze, Leibniza i Kanta postupno će voditi do njemačkoga idealizma te konačnoga svođenja duha na materiju u obliku ateističkoga materijalizma i evolucionizma. Usp. I. DEVČIĆ, Podrijetlo i značenje pojma »duh « u europskoj filozofskoj i religioznoj misli, u: Riječki teološki časopis 7(1999.) 1, 3-22., ovdje 10-11.

${ }^{31}$ Usp. R. PAVLIĆ, Doprinos Drugoga vatikanskog sabora čovjeku kao teološkoj temi, u: Diacovensia 22(2014.)3, 315-328.

${ }^{32}$ Usp. I. DEVČIĆ, Podrijetlo i značenje pojma $\gg$ duh « u europskoj filozofskoj i religioznoj misli, 21.

${ }^{33}$ EG, br. 261.

${ }^{34}$ Usp. EG, br. 261.

${ }^{35}$ EG, br. 259.

${ }^{36}$ EG, br. 280.

${ }^{37}$ Usp. EG, br. 264.
} 
druge $\ll .{ }^{38}$ Izvor i plod takve duhovnosti jest prijateljstvo s Isusom koje rađa bratskom ljubavlju i daje snažno jamstvo nade Kristovim učenicima u ovome svijetu. ${ }^{39}$

Franjin govor o Duhu Svetome bitno je kristocentrične i ekleziocentrične naravi. Isus želi Duhom ispunjene evangelizatore ${ }^{40}$. $\gg$ Sam Isus uzor je evangelizacijskog izbora. $\ll{ }^{41} S$ Kristovom spasenjskom univerzalnošću usko je povezana spasenjska univerzalnost Duha Svetoga. ${ }^{42}$ U kontekstu Franjina govora o evangelizaciji uvijek je riječ o jedinstvenom, povezanom i nerazdvojivom spasenjskom djelovanju Duha i Krista, odnosno o $\gg$ tajanstvenom djelovanju Uskrsloga i njegova Duha ${ }^{43}$

\subsection{MARIJA}

Ekleziokristocentričnu perspektivu i naučiteljski kontinuitet otkrivamo i kod Franjina govora o Mariji. Njezinu nazočnost prepoznajemo na dvama početcima: na početku Isusova javnoga djelovanja (Iv 2, 1-12) i na početku Crkve (Dj 2, 1-13). ${ }^{44}$ Podsjetimo da još papa Pavao VI. u posljednjim brojevima svoje pobudnice govori o nutarnjim pokretačkim stavovima evangelizatora, gdje zajedno $s$ vjernošću Duhu Svetomu i istini spominje i Marijinu nazočnost, kao jedan od nužnih uvjeta za plodnu evangelizaciju. ${ }^{45}$ Drugi vatikanski koncil ističe već spomenutu pneumatološku povezanost Krista, Marije i Crkve. ${ }^{46}$ Istim slijedom papa Ivan Pavao II. u enciklici Redemptoris Mater ističe Marijinu ulogu u nastanku Crkve. Time upućuje na kontinuitet Marijina majčinstva: »U ekonomiji milosti, ostvarenoj djelovanjem Duha Svetoga, postoji posebna povezanost između trenutka utjelovljenja Riječi i trenutka rođenja Crkve. Osoba koja ujedinjuje ta dva trenutka je Marija: Marija u Nazaretu i Marija u dvorani posljednje večere u Jeruzalemu. U oba slučaja njena diskretna ali bitna prisutnost upućuje na put rođenja Duha. Tako ona koja je pri-

${ }^{38}$ EG, br. 281. Papa Franjo posebnu pozornost posvećuje upravo zagovornoj molitvi kao najboljem sredstvu suvremene evangelizacije. Upravo o tome govori u svojoj posljednjoj pobudnici Gaudete et exultate. Usp. FRANJO, Gaudete et exultate - Radujte se i kličite. Apostolska pobudnica pape Franje o pozivu na svetost u suvremenom svijetu, Zagreb, ${ }^{2} 2018$., br. 154.

${ }^{39}$ Usp. EG, br. 265, 271.

${ }^{40}$ Usp. EG, br. 259.

${ }^{41}$ EG, br. 269.

${ }^{42}$ Usp. MEĐUNARODNO TEOLOŠKO POVJERENSTVO, Kršćanstvo i religije, Zagreb, 1999., br. 60; N. BIŽACA, Kršćanstvo, relativizam, religija. Razmišljanja kard. Ratzingera i Međunarodne teološke komisije, u: Ogledi iz Teologije religija, Zagreb, 2008., 135.

${ }^{43}$ Usp. EG, br. 275-280.

${ }^{44}$ Usp. EG, br. 284.

${ }^{45}$ Usp. EN, br. 82.

${ }^{46}$ Usp. AG, br. 4. 
sutna u Kristovu otajstvu kao majka, postaje - po volji Sina i po djelovanju Duha Svetoga - prisutna u otajstvu Crkve. I u Crkvi nastavlja biti majčinska prisutnost, prema riječima izgovorenim na Križu: 'Ženo, evo ti sina'; 'Evo ti majke.' « ${ }^{47}$

Nadahnut upravo tim evanđeoskim riječima papa Franjo promatra Mariju kao Isusov dar svojemu narodu te prepoznaje duboku povezanost »između Marije, Crkve i svakog vjernika $\ll{ }^{48}$ On u Mariji prepoznaje trostruki uzor: uzor majčinskoga - misionarskoga djelovanja, uzor kontemplacije te uzor savršenoga spoja akcije i kontemplacije, štoviše, » pravednosti, nježnosti i kontemplacije $\ll .{ }^{49} \mathrm{Kao}$ takva, Marija je savršen uzor same evangelizacije te upravo stoga uvijek iznova zaslužuje časni naslov: Zvijezda nove evangelizacije. Taj naslov papa Franjo dodjeljuje joj u završnim riječima svoje pobudnice u kojima zapravo izriče i samu nakanu svoga apostolskoga poslanja: »Djevice slušanja i kontemplacije, majko ljubavi, zaručnice vječnog slavlja, moli za Crkvu, čija si najčišća slika, da se nikada ne zatvori u sebe i nikada ne posustane u svojoj velikoj ljubavi za uspostavom Kraljevstva. Zvijezdo nove evangelizacije, pomozi nam da budemo svijetli svjedoci zajedništva, služenja, gorljive i velikodušne vjere, pravde i ljubavi prema siromašnima, da radost evanđelja dopre do nakraj zemlje i svojim svjetlom obasja i periferije svijeta. $\ll^{50}$

Promatrajući marijanski aspekt papinskoga govora o evangelizaciji, nameće nam se nužnost pozitivnoga vrjednovanja pučke religioznosti hrvatskoga naroda u kojem upravo Marijin lik ima nezamjenjivu ulogu. Sjetimo se da je upravo to naglasio papa Ivan Pavao II. pri svome drugome posjetu Hrvatskoj, 1998. godine, ovim riječima: »Ovo će dakle putovanje biti u znaku pobožnosti hrvatskoga naroda prema Presvetoj Bogorodici. Želim zbog toga već sada Onoj, koju nazivate kao Odvjetnicu Hrvatske, najvjerniju Majku, povjeriti svoje korake u vašoj domovini. $\ll^{51}$

\subsection{RADOST}

Temu radosti koja se proteže cijelim tekstom Franjine pobudnice nalazimo i u samom naslovu iste: Radost evandelja. Upravo tu temu duhovne pretpostavke evangelizacije rado su obrađivali brojni autori. Čini nam se da je izričita namjera pape

\footnotetext{
${ }^{47}$ IVAN PAVAO II., Redemptoris mater - Otkupiteljeva majka. Enciklika o blaženoj Djevici Mariji u životu Crkve na putu, Zagreb, ${ }^{2}$ 1994. (= RMa), br. 24.

${ }^{48}$ Usp. EG, br. 285-286.

${ }^{49}$ Usp. EG, br. 286, 288.

${ }^{50}$ EG, br. 288.

${ }^{51}$ IVAN PAVAO II., Govor u zagrebačkoj zračnoj luci Pleso, u: ISTI, Bit ćete mi svjedoci, Govori za vrijeme pastoralnog pohoda Hrvatskoj od 2. do 4. listopada 1998., Zagreb, 1998., 7. Više o pozitivnom vrjednovanju marijanske pučke religioznosti u hrvatskome narodu, usp. B. Z. ŠAGI, Marijin lik, pučka religioznost i crkvenost u hrvatskoj tranziciji, u: Svesci 100(2000.), 82-88.
} 
Franje predstaviti radost kao temeljni nutarnji stav misijske duhovnosti, odnosno evangelizacijskoga pastorala. Njegova je nakana probuditi svijest da je kod evangelizacije, više nego na djelovanju, naglasak na nutarnjem stavu evangelizatora. Izuzetno je teško, ako ne i nemoguće, komunicirati radost ako je sami nismo iskusili kao radost spasenja. U duhu kontinuiteta s Pavlom VI., pozivajući se na Evangelii nuntiandi, papa Franjo poziva da ponovno otkrijemo: »blagu i okrepljujuću radost naviještanja, pa i onda kada treba sijati u suzama. (...) I neka svijet našeg vremena koji traži, sad u tjeskobi, sad u nadi, uzmogne primiti Radosnu vijest ne od tužnih i malodušnih, nestrpljivih i tjeskobnih navjestitelja, nego od službenika evanđelja čiji život ižaruje žarom, koji su prvi u sebe primili Kristovu radost. $\ll^{52}$

Izvor evanđeoske radosti jest $\mathrm{u}$ Bogu, u zajedništvu života $\mathrm{s}$ Bogom te iskustvu susreta s Božjom ljubavlju koja prašta i zacjeljuje. To je specifikum kršćanske radosti koji otkrivamo već u čovjekovoj stvorenjskoj naravi. ${ }^{53}$ Upravo to želi naglasiti papa Franjo kad govori o evanđelju koje »odgovara na najdublje potrebe osoba, jer svi smo stvoreni za ono što nam evanđelje nudi: prijateljstvo s Isusom i bratsku ljubav $\ll^{54}$. Ispunjenje te čovjekove stvorenjske čežnje za samim Izvorom radosti papa Franjo vidi u čovjekovoj dvostrukoj otvorenosti: prema Kristu i prema svijetu. Otvorenost prema Kristu interpretira riječima kontemplacije i zaljubljenosti, ${ }^{55}$ dok otvorenost prema svijetu promatra u koncilskom duhu dijeljenja radosti i nade te prijateljskoga i bratskoga svjedočenja razloga vlastite nade: $\gg$ Istina je da smo u našem odnosu sa svijetom pozvani dati razloga svojoj nadi, ali ne kao neprijatelji koji upiru prstom i osuđuju. $\ll{ }^{56} \mathrm{U}$ takvoj bratskoj otvorenosti srca prema bližnjima i svijetu papa Franjo prepoznaje pravi izvor kršćanske radosti. ${ }^{57}$

Sve to odnosi se u prvom redu na $\gg$ službenike evanđelja «, na one kojima je povjerena spomenuta »blaga i okrepljujuća radost naviještanja « evanđelja. Ne čudi nas stoga što upravo tema svećeničke radosti privlači pozornost pojedinih autora u interpretaciji Papine pobudnice. Slijedom poticaja pape Franje promišljaju se aktualne bipolarne teme zapreka i putova svećeničke radosti, ${ }^{58}$ žalosti i radosti navjestitelja

\footnotetext{
${ }^{52}$ EN, br. 75; usp. EG, br. 10.

${ }^{53}$ Usp. R. PAVLIĆ, Radost kao blaženstvo, u: Bogoslovska smotra 85(2015.)4, 1077-1092.

${ }^{54}$ EG, br. 265.

${ }^{55}$ Usp. EG, br. 266.

${ }^{56} \mathrm{EG}$, br. 271.

${ }^{57}$ Usp. EG, br. 272.

${ }^{58}$ Usp. D. VUKOVIĆ, Svećenik i radost - od iskustva do navještaja evanđelja, u: Diacovensia 22(2014.)4, 497-513.
} 
radosne vijesti ${ }^{59}$ te tema svećeničkoga zajedništva i bratstva kao uvjeta radosnoga naviještanja evanđelja. ${ }^{60} \mathrm{Uz}$ govor o svećeničkoj radosti, u duhu poticaja Papine pobudnice, i ovdje se, među ostalim, ističu naše prethodne dvije teme: otvorenost Duhu Svetomu i zajedništvo s Marijom. Otvorenost Duhu Božjemu »koji uvijek puše i nadahnjuje one koji mu se otvaraju « spada u jedan od temeljnih putova prema iskustvu svećeničke radosti, ${ }^{61}$ dok se zajedništvo s Marijom promatra kao dioništvo sinovske radosti. ${ }^{62}$

\section{Zaključak}

U našem promišljanju riječi pape Franje na temu evangelizacije koju nalazimo u njegovoj pobudnici Evangelii gaudium, osobito u posljednjem poglavlju, naslovljenom Duhom ispunjeni evangelizatori, naglasak smo stavili na naučiteljski kontinuitet pape Franje u odnosu na njegove prethodnike. Unatoč novim naglascima koje otkrivamo kod pape Franje, njegov naučiteljski kontinuitet dolazi do izražaja u samom poimanju evangelizacije is njome povezanoga misijskoga djelovanja Crkve te redovitoga pastorala. To potvrđuju i tri teme koje smo posebno istaknuli u kontekstu govora o duhovnim pretpostavkama evangelizacije: otvorenost Duhu Svetomu, zajedništvo s Marijom te radosno navještenje evanđelja u suvremenom svijetu.

Ako ovdje obrađivanu pobudnicu Evangelii gaudium pokušamo sagledati u kontekstu ostalih Papinih svakodnevno izgovorenih ili napisanih riječi, možemo reći da ta pobudnica predstavlja svojevrsno programsko djelo Franjina pontifikata. I ovdje dakle otkrivamo određeni Franjin kontinuitet u obliku dosljednoga ispunjenja vlastitoga pontifikata. Sjetimo se da temu radosnoga naviještanja evanđelja susrećemo još u njegovoj prvoj enciklici naslovljenoj Lumen fidei. ${ }^{63}$ Ista tema nastavlja se u njegovim govorima o misijskom poslanju Crkve. Ako za primjer uzmemo njegovu poruku za Svjetski misijski dan 2014. godine, ${ }^{64}$ u njoj na sažet način, u samo pet brojeva teksta, nalazimo gotovo sve ovdje izdvojene naglaske: misionarsku narav

${ }^{59}$ Usp. M. PARLOV, Žalosti i radosti navjestitelja radosne vijesti, u: Riječki teološki časopis 23(2015.)1, 61-84.

${ }^{60}$ Usp. B. STELLA, Svećeničko bratstvo: zajedništvo za poslanje, u: Riječki teološki časopis 23(2015.)1, 5-18.

${ }^{61}$ Usp. D. VUKOVIĆ, Svećenik i radost - od iskustva do navještaja evanđelja, 512.

${ }^{62}$ Usp. M. PARLOV, Žalosti i radosti navjestitelja radosne vijesti, 80-83.; B. STELLA, Svećeničko bratstvo, 9.

${ }^{63}$ FRANJO, Lumen fidei - Svjetlo vjere. Enciklika vrhovnog svećenika Franje biskupima, prezbiterima $i$ dakonima, posvećenim osobama i svim vjernicima laicima o vjeri, Zagreb, 2013., br. 37-49.

${ }^{64}$ FRANJO, Poruka za Svjetski misijski dan 2014., Vatikan, 2014. Prijevod teksta i kratko teološko tumačenje: I. MACUT, Poruka pape Franje za Svjetski misijski dan 2014., u: Diacovensia 22(2014.)3, 381-393. 
Crkve koja odgovara njezinu trojstvenom božanskom Izvoru; trajna zadaća radosnoga naviještanja evanđelja svih kršćana u snazi Kristova Duha te konačno trajni spomen na Djevicu Mariju koju naziva uzorom ponizne i radosne evangelizacije te uzrokom naše radosti.

Možemo zaključiti da Franjina vizija Duhom ispunjenih evangelizatora odgovara trojstvenoj ekleziologiji Drugoga vatikanskoga koncila, kojoj je svojstvena misionarska vizija Crkve u njezinoj trajnoj otvorenosti svijetu sa zadaćom radosnoga naviještanja evanđelja. Iako otvoreno govori o problemima u Crkvi koji mogu biti zaprjeka radosnomu širenju evanđelja, papa Franjo ne gubi iz vida Kristovo obećanje vlastite nazočnosti u snazi njegova Duha te snagu Marijina zagovora. To dvoje jamstvo je radosti današnjih evangelizatora. 


\title{
SPIRIT-FILLED EVANGELIZERS
}

\author{
Richard PAVLIĆ*
}

Summary: Spirit-filled evangelizers is the title of the fifth chapter of Pope Francis' apostolic exhortation Evangelii Gaudium. The article reflects on the so-called spiritual postulates of evangelization which are found in this part of the Pope's exhortation. The text of the article is divided in three parts. In the first part, we briefly examine the terms of evangelization and missionary activity of the Church through the historical development of papal thought form Pope Paul VI, through John Paul II and Benedict XVI, to Pope Francis. Along the same lines, in the second part, we examine the idea of evangelization in the thought of Pope Francis through the prism of continuity and novelty regarding his predecessors. The third part of the article brings our main topic, the discourse on the Spirit-filled evangelizers where we select three spiritual postulates of evangelization suggested by Pope Francis: openness to the Holy Spirit, communion with Mary and the conditional-consequential topic of the joy of the fruitful proclamation of the Gospel.

Keywords: evangelization, new evangelization, missions, Paul VI, John Paul II, Benedict XVI, Francis, Evangelii Gaudium.

* Asst. Prof. Richard Pavlić, Ph. D., Theology of Rijeka, Dislocated Studies of Catholic Faculty of Theology, University of Zagreb, Omladinska 1, 51000 Rijeka, Croatia, ripavlic@gmail.com 